Open Access

\title{
Factors influencing taxpayers to engage in tax evasion: evidence from Woldia City administration micro, small, and large enterprise taxpayers
}

Erstu Tarko Kassa (D)

Correspondence: erstu0910@gmail. com

Woldia University, Woldia, Ethiopia

\begin{abstract}
The main purpose of this paper is to investigate factors that influence taxpayers to engage in tax evasion. The researcher used descriptive and explanatory research design and followed a quantitative research approach. To undertake this study, primary and secondary data has been utilized. From the target population of 4979, by using a stratified and simple random sampling technique, 370 respondents were selected. To verify the data quality, the exploratory factor analysis (EFA) was conducted for each variable measurements. After factor analysis has been done, the data were analyzed by using Pearson correlation and multiple regression analysis. The finding of the study revealed that the relationship between the study independent variables with the dependent variable was positive and statistically significant. The regression analysis also indicates that tax fairness, tax knowledge, and moral obligation significantly influence taxpayers to engage in tax evasion, and the remaining moral obligation and subjective norms were not statistically significant to influence taxpayers to engage in tax evasion.
\end{abstract}

Keywords: Tax evasion, Tax knowledge, Tax fairness, Moral obligation

\section{Introduction}

In developed and developing countries, business owners, government workers, service providers, and other organizations are forced by the government to pay a tax for a long period in human being history, and no one can escape from the tax of the country. To support this, there is an interesting statement mentioned by Benjamin Franklin "nothing is certain except death and taxes". This statement confirmed that every citizen should be subjected to the law of tax, and they are obliged to pay the tax from their income. To build large dams, to construct transportation infrastructures, and to provide quality social services for the community, collecting a tax from citizens plays a significant role for the governments (Saxunova and Szarkova, 2018). 
Tax is the benchmark and turning point of the country's overall development and changing the livelihoods and enhancing per capital income of the individuals. The gross domestic product of the developed countries and average revenue ratio were $35 \%$ in the year 2005, whereas in developing countries the share was $15 \%$ and in third world countries also not more than $12 \%$ (Mughal, 2012).

In the developing world, countries have no system to collect a sufficient amount of tax from their taxpayers. The expected amount of revenue cannot be enhanced due to different reasons. Among the reasons tax operation of the system may not be smooth, tax evasion and lack of awareness creation for the taxpayers are common in the developing world, and citizens are not committed to paying the expected amount of tax for their countries (Fagbemi et al., 2010). In today's world, this remains very much the same as persons now pay taxes to their governments. As the world has evolved, tax compliance has taken a back seat with tax avoidance and tax evasion being at the forefront of the taxpayer's main objective. Tax avoidance is the use of legal means to reduce one's tax liability while tax evasion is the use of illegal means to reduce that tax liability (Alleyne \& Harris, 2017). Tax evasion is a danger to the community; the countries and international organizations have been making an effort to fight undesirable phenomena related to taxation, the tax evasion, or tax fraud (Saxunova and Szarkova, 2018).

Tax evasion may brings a devastating loss for the country's GDP at the micro level, and it became a debatable and a special concern for tax collector authorities (Aumeerun et al., 2016). The participants in tax evasion activity critized by different individuals and groups by considering the loss that brings to the country economy (Alleyne \& Harris, 2017).

According to Dalu et al., (2012) state that in the Zimbabwe tax system there are identical devils tax evasion and tax avoidance that create a problem for the government to collect a tax from taxpayers. Like Zimbabwe, many nations have faced challenges to cover the annual budget and to construct different infrastructures due to the budget deficit created by tax evasion (Alleyne \& Harris, 2017; Turner, 2010).

Scholars especially economists agreed that tax evasion may be considered a technical problem that exists in the tax collection system, whereas psychologists believed that tax evasion is a social problem for the countries (Terzić, 2017).

Tax evasion practices are more worsen in developing countries than when we compare against the developed countries. Tax evasion is like a pandemic for the countries because they are unable to control it. Therefore, governments were negatively affected by tax evasion to improve the life standard of its citizens and to allocate a budget for public expenditure, and it became a disease for the country's economy and estimated to cost $20 \%$ of income tax revenue (Ameyaw et al., 2015; degl'Innocenti \& Rablen, 2019; Palil et al., 2016).

Several factors may lead taxpayers to engage in tax evasion. Among the factors, tax knowledge, tax morale, tax system, tax fairness, compliance cost, attitudes toward the behavior, subjective norms, perceived behavioral control, and moral obligation are major factors (Alleyne \& Harris, 2017; Rantelangi \& Majid, 2018). Other factors have also a significant effect on taxpayers to engage in tax evasion practice such as capital intensity, leverage, fiscal loss, compensation, profitability, contextual tax awareness, 
interest rate, inflation, average tax rate, gender, and ethical tax awareness on tax evasion (Annan et al., 2014; AlAdham et al., 2016; Putra et al., 2018).

According to Woldia City Administration Revenue Office annual report (2019/2020) from July 1, 2019, to June 30, 2020, 232,757,512 birr was planned to be collected from taxpayers; however, the office was able to collect only 198,537,785.25 birr; however, the remaining 34,219,726.75 birr have not been collected by the office from the taxpayers. The reason behind this was there might be some factors that lead to taxpayers not to pay the annual tax from their annual income. Based on the review of the previous studies and by diagnosing the tax collection system in the city administration, the researcher identified the gaps. The first gap that motivated the researcher to undertake this study is that the prior studies did not address the factors that influence the tax collection system of Ethiopia, specifically, there is no research result that was able to show which factors influence taxpayers to engage in tax evasion in the Woldia city administration. The other gap is the previous study focused on the demographic, economic, social, and other factors. However, this study mainly focused on the behavioral and other factors that lead taxpayers to engage in tax evasion.

To indicate the benefit of this study, the study specifies on which critical factors the authority will focus on to enhance annual revenue and to aware tax payers of the devastating impact of tax evasion. Moreover, the paper may bring new insights on tax evasion influential non-economic factors that the researchers may give more emphasis on the upcoming researches. This paper will also contribute innovative ways to know the reasons why tax payers engage in tax evasion and inform the authority at which factors they will struggle to reduce their influence and to enhance revenue. The study can be an evidence that the tax authority should launch innovative techniques to control tax evasion practices. Moreover, applying fair tax system in the collectors' side, the enterprises become innovative and will expand their business.

To sum up, in this study, the researcher examined which factor (tax knowledge, tax fairness, subjective norms, moral obligation, and attitude towards the behavior) influences taxpayers to engage in tax evasion activities. Based on the above discussion, the objective of the study is to examine factors that influence taxpayers to engage in tax evasion in Woldia city administration.

\section{Literature review}

\section{Tax and tax evasion}

Tax is charged by the government to the business, governmental organization, and individual without any return forwarded from the authority. Tax can be categorized as direct tax which is collected from the profit of the companies and the incomes of individuals, and the other category of tax is an indirect tax collected from consumers' payment (James and Nobes, 1999).

Tax evasion is a word explaining individuals, groups, and companies rejecting the expected amount of payment for the authority. It is a criminal offense on the view of law (Nangih \& Dick, 2018). The overall procedure of tax collection faced different challenges especially tax evasion the most important one. Tax evasion is done intentionally by taxpayers by avoiding and hiding different documents that become evidence for the tax collection authorities. It is simply an illegal act to pay the true amount of the tax 
(Aumeerun et al., 2016; Storm, 2013). Tax evasion is a crime that is able to distort the overall economic, political, and social system of the country. The economic aspect of tax evasion affects fair distribution of wealth for the citizens. The social aspect also creates different social groups motivated by tax evasion discouraged by these individuals due to unfair competition (AlAdham et al., 2016). Tax evasion is a mal-activity that reduces the amount of tax paid by the payers. Perhaps the taxpayers who engaged in evasion activity may be supported by the legislative of the country (Kim, 2008; Putra et al., 2018; Allingham \& Sandmo, 1972). According to Al Baaj et al. (2018) argument, there are two types of tax evasions. The first one is the legal evasion or tax avoidance which is supported by the legislation of the countries and the right is given for the taxpayer, but it is not constitutional (Gallemore \& Labro, 2015; Zucman, 2014).

\section{Theoretical reviews on factors affecting tax evasion}

The illegal activity done by taxpayers has many determinants that lead them to engage in tax evasion. Among the factors that trigger taxpayers who participate in this activity are the economic factors. Under the economic factors, business sanctions, business stagnation, and the amount of tax burden are considered as influential factors. On the other hand, legal factors, social factors, demographic factors, mental factors, and moral factors are the most important factors (Saxunova and Szarkova, 2018). Many factors determine the taxpayers' interest to engage in tax evasion. Among the factors, the following are considered under this review.

The factors that able to influence taxpayers to engage in tax evasion are moral obligation. It is a principle and a duty of taxpayers by paying a reasonable amount of tax for the tax authorities without the enforcement of others. It is an intrinsic motivation of payers paying the tax (Sadjiarto et al., 2020). When taxpayers have low tax morals, they will become negligent to pay their allotted tax, and they will engage in tax evasion (Alm \& Torgler, 2006; Frey \& Oberholzer-Gee, 1997; Torgler et al., 2008). According to Feld and Frey (2007), when tax officials are responsible and provide respect in their duties toward taxpayers, tax morale or the honesty of taxpayers will increase. Tax morals may be affected by a demographic and another factor like income level, marital status, and religion (Rantelangi \& Majid, 2018). It is the determinant behavior of tax payers whether they participate or not. Tax morals can affect positively taxpayers to engage in tax evasion (Nangih \& Dick, 2018; Terzić, 2017). It is known that taxes levied by the concerned authority are ethical. As cited by Ozili (2020), McGee (2006) argues that there are three basic views on the ethics and moral of tax evasion. The first view is tax evasion is unethical and should not be practice by any payer, the second argument deals that the state is illegal and has no moral authority to take anything from anyone, and the last argument is tax evasion can be ethical under some conditions and unethical under other situations; therefore, the decision to evade tax is an ethical dilemma which considers several factors (Robert, 2012). Therefore, the discussion leads to the following hypothesis:

$H_{1}$. Moral obligation has a negative influence on taxpayers to engage in tax evasion. 
The other factor that influences taxpayers to engage in tax evasion is tax fairness. Tax fairness is a non-economic factor that determines the tax collection of the country (Alkhatib et al., 2019). It is known that the tax collection procedures, principles, and implementation must be fair. Unethical behavior may happen due to the unfairness of the tax collection process. The fairness of tax may influence payers positively to pay the tax. When the tax rate is not reasonable and fair, the payers will regret to engage in the tax evasion practices and they will inform authorities their annual income without denying the exact amount. Considering the ability of paying or acceptable tax rates helps to maintain the fairness of the taxation system (Rantelangi \& Majid, 2018). The governments choose to levy in what amounts and on whom will pay a high tax rate (Thu, 2017). The tax rate is a factor that induces taxpayers to pay less amount from their income. The rate of tax should be fair and reasonable for the payers (Ozili, 2020). As cited by Gandhi et al. (1995) the Allingham and Sandmo's model, Allingham and Sandmo (1972) shows that the tax rate on payment can be positive, zero, or negative, which implies that an increase in the tax rate may cause the tax payment to increase, remain the same, or decrease. The theoretical literature could not evidence the claim that an increase in the tax rate will lead to an increase in tax evasion (Gandhi et al., 1995). The fairness of tax is controversial and argumentative because there may not happen a similar amount of tax for all payers (Abera, 2019). Thus, based on this ground the study hypothesis would be:

\section{$H_{2}$. Tax fairness has a positive influence on taxpayers to engage in tax evasion.}

Tax knowledge is vital for taxpayers to know the cause and effect brought to them to engage in tax evasion. If tax payers are well informed about tax evasion, their participation in tax evasion would be infrequent; the reverse is true for a taxpayer who is not well informed. Tax-related information should give more emphasis to enhance the knowledge of taxpayers and experts of the authority (Poudel, 2017). Tax knowledge is a means to enhance the revenue of the country from the side of tax payers (Sadjiarto et al., 2020). If the authorities cascade different training for taxpayers about tax evasion and other tax-related issues, taxpayers become reluctant to engage in tax evasion (Rantelangi \& Majid, 2018). Tax knowledge is a determinant factor for the taxpayer to engage and retain from the tax evasion activities (Abera, 2019). When taxpayers are undertaking their routine tasks without tax knowledge, they may involve in certain risks that expose them to engage in tax evasion (Thu, 2017). Thus, the discussion leads to the following hypothesis:

\section{$H_{3}$. Tax knowledge has a negative influence on taxpayers engaged in tax evasion.}

The stakeholders, government experts, families, individuals, groups, and peers influence taxpayers whether they engaged in tax evasion or not (Alleyne \& Harris, 2017). As cited by Alkhatib et al. (2019), the influence of peer groups on tax taxpayers is high, thus affecting the taxpayers' preferences, personal values, and behaviors to engage in tax evasion (Puspitasari \& Meiranto, 2014). The stakeholders around the taxpayers might be motivators to push taxpayers in the criminal act of tax evasion. This act called subjective norms meant that the payers are influenced by peers and other stakeholders. 
When the tax payer is reluctant to pay a tax for the authority, his/her friends are more likely to hide tax. As cited by Abera (2019), there is a strong relationship between social norms and subjective norms with tax evasion and affects the small business taxpayers (Nabaweesi, 2009). The above discussion can support the following hypothesis of the study:

\section{$H_{4}$. Subjective norms have a positive influence on taxpayers to engage in tax evasion.}

The other factor that influences taxpayers to engage in tax evasion is an attitude towards the behavior of taxpayers. Attitude is a means of evaluating the activities whether they are positive or negative of any object. Many studies have been done by different scholars by defining and identifying the relationship between the attitudes of taxpayers with tax evasion (Alleyne \& Harris, 2017). If the attitude of taxpayers towards taxation is negative, they will be reluctant to pay their obligation to the authority; the reverse is true when taxpayers have positive attitudes towards taxation (Abera, 2019). Based on the above discussion, the hypothesis of the study would be as follows:

$H_{5}$. Tax payers' attitude towards the behavior has a positive influence on taxpayers to engage in tax evasion.

\section{Conceptual framework of the study}

The researcher identified the variables and presented the relationship between independent and dependent variables as follows (Fig. 1):

\section{Materials and methods}

The researcher applied descriptive and explanatory research design to carry out this study. The explanatory research design enables the researcher to show the cause and effect relationship between independent and dependent variables, and the descriptive

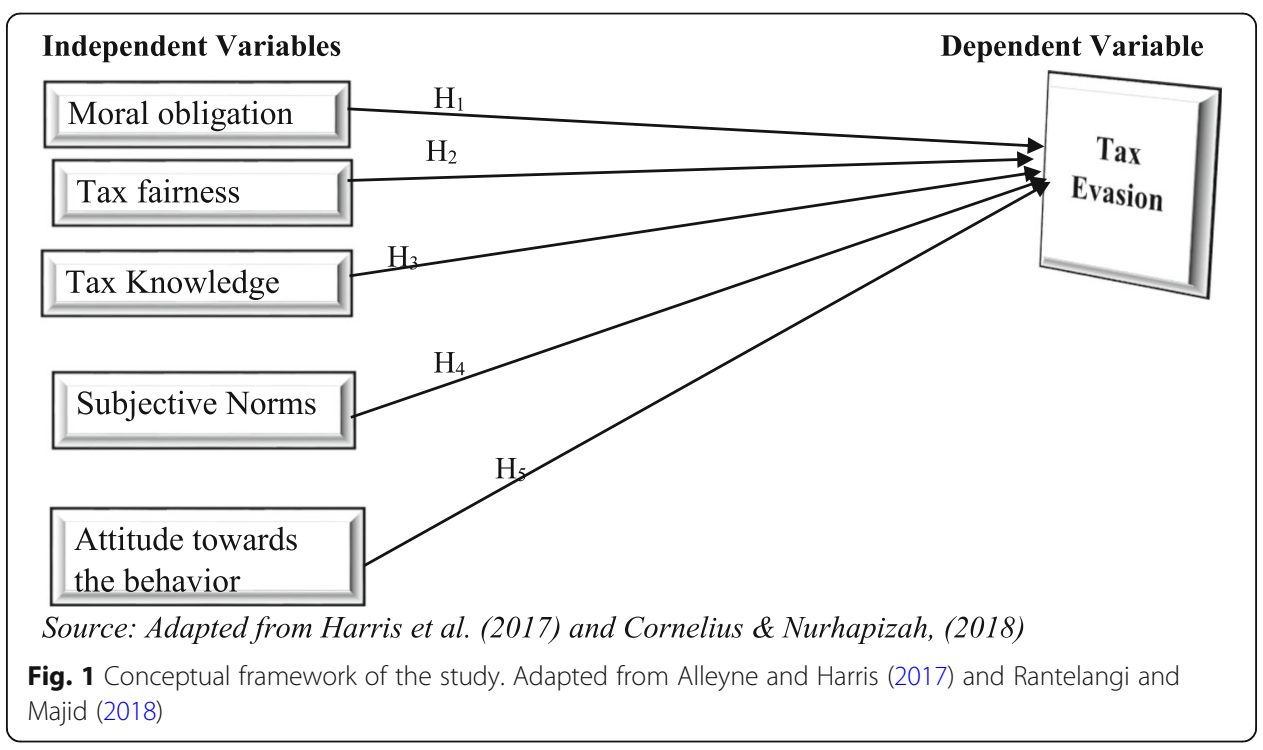


research also helps to describe the event as it is. The quantitative approach has been followed by the researcher to analyze and interpret the numerical data collected from the respondents. The researcher used primary and secondary data. The primary data was collected from the respondents by using questionnaires, and the secondary data was also collected from the reports, websites, and other sources.

The target population of the study was 4979 taxpayers (micro, small, and large enterprises). From the total taxpayers, 377 are categorized under level "A," 207 are under level "B," and the remaining 4395 taxpayers are categorized under level "C". From the target population by using a stratified sampling technique, the respondents have been selected. The target population has been divided by the level of taxpayers; after dividing the population by level, the researcher applied a simple random sampling technique to select respondents. To identify the target participants or sample size in this study, the researcher used Yamane's (1967) formula. Hence, the formula is described as follows:

$$
n=\frac{N}{1+N(e)^{2}}
$$

where $N=$ target population, $n=$ sample size, $e=$ error term

$$
\begin{aligned}
& n=\frac{4979}{1+4979(0.05)^{2}} \\
& n=\mathbf{3 7 0}
\end{aligned}
$$

Based on the sample size, the respondents have participated proportionally as follows from each level. The total population was divided by strata based on the level categorized by the authorities. By using a simple random sampling technique, 28 respondents were from level "A," 15 respondents from level "B," and 327 respondents from level "C" have participated.

Regarding data collection instruments, the data was collected by self-administered standardized questionnaires. The variable of the study a moral obligation was measured by 4 items; after conducting factor analysis, the fourth variable or questionnaire has been removed and after that correlation and regression analysis has been done for 3 items; the value of Cronbach's alpha was .711; the other factor attitude towards the behavior was measured by 4 items with a value of .804 Cronbach's alpha; the third variable subjective norms was also measured by 4 items; the value of Cronbach's Alpha was .887 , and tax evasion was measured by 5 items; the Cronbach's alpha value was .868. For the above-listed variables, the questionnaires were adapted from Alleyne and Harris (2017), and the remaining variable tax fairness was measured by 7 items, the Cronbach's alpha value was .905, the items were adapted from Benk et al. (2012), and the last variable tax knowledge was measured by 5 items. However, after conducting factor analysis, the fifth item has been removed due to low value of the variable. After the removal of the fifth item, the Cronbach's alpha value for the remaining items was .800, the items were adapted from Poudel (2017). For all variables, the researcher has used a five-point Likert scale from strongly agree to strongly disagree.

To analyze the collected data, the researcher used descriptive statistics analysis, factor analysis, correlation analysis, and multiple regression analysis to know the result of 
variables by using SPSS Version 22. Moreover, the model of the study is described as follows:

$$
Y=B_{0}+\beta_{1} X_{1}+\beta_{2} X_{2}+\beta_{3} X_{3}+\beta_{4} X_{4}+\beta_{5} X_{5}+e
$$

where $Y=\operatorname{tax}$ evasion, $X_{1}=$ moral obligation, $X_{2}=$ tax fairness, $X_{3}=\operatorname{tax}$ knowledge, $X_{4}$ = subjective norms, and $X_{5}=$ attitude towards the behavior, $\beta=$ beta coefficient, $B_{0}=$ constant, $e=$ other factors not included in the study ( 0.05 random error).

\section{Results and discussion}

\section{Level of respondents}

As indicated in Table 1 from the total respondents, $88.4 \%$ are categorized under level "C," $4.1 \%$ are leveled under "B," and the remaining $7.6 \%$ of respondents have been categorized under level "A".

\section{Factor analysis of the study variables}

To undertake exploratory factor analysis, the data should fulfill the following assumptions. The first assumption is the variables should be ratio, interval, and ordinal; the second one is within the variables there should be linear associations; the third assumption is a simple size should range from 100 to 500; and the last assumption is the data without outliers. Thus, this study data have been checked by the researcher whether the data meets the assumption or not. After checking the assumptions, factor analysis was conducted as follows.

\section{KMO and Bartlett's test}

Conducting KMO and Bartlett's test is a precondition to conduct the factor analysis of the study measuring variables. KMO measures the adequacy of the sample of the study. In the result reported in Table 2, the value was 0.883 and enough for the factor analysis. Related with Bartlett test as shown in Table 2, the value is $5727.623(p<0.001)$, which reveals the adequacy of data using factor analysis.

As shown in Table 3, factors were extracted from study data; there was a linear relationship between variables. From the table, we can understand that 6 variables have more than one eigenvalue. The first factor scored the value 31.782 of the variance, the second value is 11.739 of the variance, the third factor scored 8.246 of the variance, the fourth factor accounts for 6.725 of the variance, the fifth factor also accounts for 5.233, and the last factor scored 4.123 of the variance. All six factors were explained cumulatively by $67.85 \%$ of the variance.

As shown in the Fig. 2, the scree plot starts to turn down slowly at the low eigenvalue which is less than 1 . The six factors eigenvalue is greater than one.

Table 1 Tax payers level

\begin{tabular}{llllll}
\hline & & Frequency & Percent & Valid percent & Cumulative percent \\
\hline Valid & Level "A" & 28 & 7.6 & 7.6 & 7.6 \\
& Level "B" & 15 & 4.1 & 4.1 & 11.6 \\
& Level "C" & 327 & 88.4 & 88.4 & 100.0 \\
& Total & 370 & 100.0 & 100.0 & \\
\hline
\end{tabular}

Source: own survey (2020) 
Table $2 \mathrm{KMO}$ and Bartlett's test

\begin{tabular}{lll}
\hline Kaiser-Meyer-Olkin measure of sampling adequacy. & $\mathbf{. 8 8 3}$ \\
\hline Bartlett's test of sphericity & Approx. Chi-square & 5727.623 \\
& Df & 351 \\
& Sig. & .000 \\
\hline
\end{tabular}

Source: own survey (2020)

The pattern matrix is shown in Table 4 which is able to show the loading of each variable and the relationship of variables in the study. The highest value among the factors measured the variable considerably. The cutoff point of loading was set at .35 and above. Based on the loading cutoff point except two factors, all are significant and analyzed under this study. From the six variables (five independent and one dependent) incorporated under this study, the identified factors show that how significantly enough

Table 3 Total variance explained

\begin{tabular}{|c|c|c|c|c|c|c|c|}
\hline \multirow[t]{2}{*}{ Component } & \multicolumn{3}{|c|}{ Initial eigenvalues } & \multicolumn{3}{|c|}{$\begin{array}{l}\text { Extraction sums of squared } \\
\text { loadings }\end{array}$} & \multirow{2}{*}{$\begin{array}{l}\text { Rotation sums } \\
\text { of squared loadings } \\
\text { Total }\end{array}$} \\
\hline & Total & $\begin{array}{l}\% \text { of } \\
\text { variance }\end{array}$ & $\begin{array}{l}\text { Cumulative } \\
\%\end{array}$ & Total & $\begin{array}{l}\% \text { of } \\
\text { variance }\end{array}$ & $\begin{array}{l}\text { Cumulative } \\
\%\end{array}$ & \\
\hline 1 & 8.581 & 31.782 & 31.782 & 8.581 & 31.782 & 31.782 & 6.862 \\
\hline 2 & 3.170 & 11.739 & 43.521 & 3.170 & 11.739 & 43.521 & 6.456 \\
\hline 3 & 2.226 & 8.246 & 51.766 & 2.226 & 8.246 & 51.766 & 4.036 \\
\hline 4 & 1.816 & 6.725 & 58.492 & 1.816 & 6.725 & 58.492 & 3.783 \\
\hline 5 & 1.413 & 5.233 & 63.724 & 1.413 & 5.233 & 63.724 & 3.963 \\
\hline 6 & 1.113 & 4.123 & 67.847 & 1.113 & 4.123 & 67.847 & 2.991 \\
\hline 7 & .847 & 3.138 & 70.985 & & & & \\
\hline 8 & .810 & 2.999 & 73.984 & & & & \\
\hline 9 & .753 & 2.790 & 76.774 & & & & \\
\hline 10 & .611 & 2.262 & 79.035 & & & & \\
\hline 11 & .603 & 2.235 & 81.270 & & & & \\
\hline 12 & .525 & 1.944 & 83.214 & & & & \\
\hline 13 & .476 & 1.763 & 84.976 & & & & \\
\hline 14 & .440 & 1.628 & 86.605 & & & & \\
\hline 15 & .423 & 1.567 & 88.172 & & & & \\
\hline 16 & .397 & 1.471 & 89.643 & & & & \\
\hline 17 & .356 & 1.317 & 90.960 & & & & \\
\hline 18 & .348 & 1.288 & 92.247 & & & & \\
\hline 19 & .314 & 1.162 & 93.410 & & & & \\
\hline 20 & .287 & 1.064 & 94.473 & & & & \\
\hline 21 & .276 & 1.022 & 95.495 & & & & \\
\hline 22 & .253 & .937 & 96.432 & & & & \\
\hline 23 & .221 & .820 & 97.252 & & & & \\
\hline 24 & .217 & .804 & 98.057 & & & & \\
\hline 25 & .203 & .751 & 98.808 & & & & \\
\hline 26 & .173 & .642 & 99.449 & & & & \\
\hline 27 & .149 & .551 & 100.000 & & & & \\
\hline
\end{tabular}




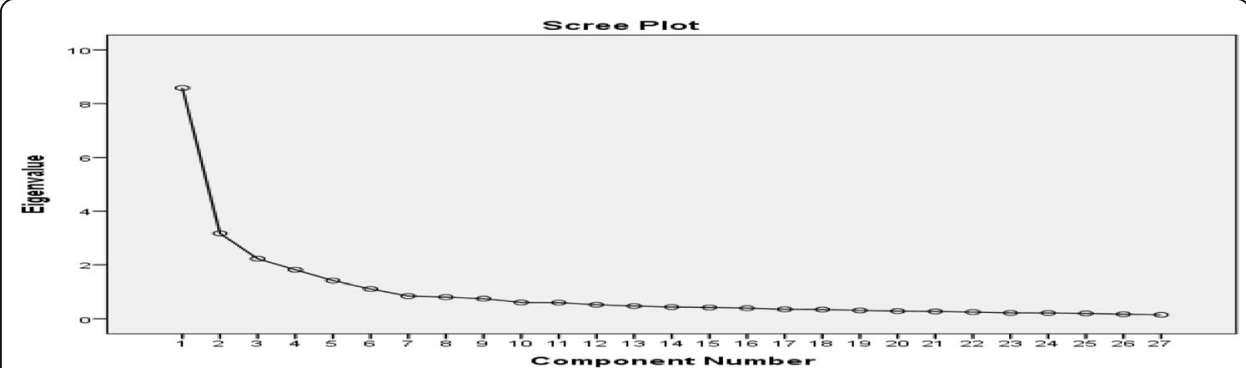

Fig. 2 Scree plot. Source: own survey (2020)

to measure the situation. These factors have scored greater than 1 eigenvalue and able to explain $67.85 \%$ of the variance. In general, the detail variables and their factor are described as follows:

The first component tax fairness has 7 factors; the eigenvalue is 8.58 and able to explain 31.78 of the total variance. In this component, the highest contributed factor was item TF3 (weight $=.925)$, TF5 (weight $=.865)$, TF1 (weight $=.859)$, TF2 (weight $=.778)$, TF4 (.668), TF6 (weight $=.614$ ), and TF7 (weight $=.568)$. The second component was tax evasion and has 5 items; the eigenvalue is 3.17 and explaining 11.73 of the variance. The factor weight of the items, TE4 (factor weight $=.860$ ), TE5 (factor weight $=.810$ ), TE3 (factor weight $=.730$ ), TE2 (factor weight $=.650$ ), and the last one is TE1 (factor weight $=$ .606). The third component was subjective norms; it has 4 factors the weight of each factor described as follows. The first item SNS1 weight $=.898$, SNS2 factor weight $=.887$, SNS4 factor weight $=.846$, and SNS3 factor weight $=.820$. Moreover, the eigenvalue of this component is 2.226 and explained 8.246 of the variance of the study. The fourth component is an attitude towards the behavior. This variable has four factors that have 1.816 eigenvalue and explained 6.725 of the total variance. Among the items, ATB2 factor weight $=.863$, ATB1 factor weight $=.792$, ATB3 factor weight $=.791$ and the last factor is ATB4 factor weight $=.500$. The fifth component of the study is tax knowledge; at the very beginning of this variable, the researcher adapted five items. However, one item (TK5) was not significant and removed from this analysis. In this component, the highest value was scored by TK3 (factor weight $=.866$ ), the second highest TK2 (factor weight $=.801$ ), the third highest factor weight (weight $=.700$ ), and the last factor is TK4 (weight $=.690$ ). The eigenvalue of this component was 1.413 and explained 5.233\% of the variance. The last component is a moral obligation; like tax knowledge, the researcher adapted for this variable 4 items, though, one item (MO4) was not significant and removed from the items list. The eigenvalue of this component was 1.113 and explained 4.123 of the variance. From the items, MO1 scored the highest factor weight of .891, the second highest weight in this component was MO3 with a factor weight of .854 , and the third highest factor weight was scored by MO3 with a value of .508 .

\section{Association analysis of the study variables}

To analyze the correlation between variables as shown in the Table 5 , the relation between subjective norms with taxpayers engaged in tax evasion is $r=0.240(p<0.05)$; this indicates that there is a statistically significant relationship between the two variables. The relationship between ATB with TE, MO with TE, TK with TE, and TF with TE, the Pearson correlation result is $r=0.318(p<0.05), r=0.371(p<0.05), .446$, and $r=0.691(p<$ 
Table 4 Pattern matrix

\begin{tabular}{|c|c|c|c|c|c|c|}
\hline & \multicolumn{6}{|c|}{ Component } \\
\hline & 1 & 2 & 3 & 4 & 5 & 6 \\
\hline TF3 & .925 & & & & & \\
\hline TF5 & .865 & & & & & \\
\hline TF1 & .859 & & & & & \\
\hline TF2 & .778 & & & & & \\
\hline TF4 & .668 & & & & & \\
\hline TF6 & .614 & & & & & \\
\hline TF7 & .568 & & & & & \\
\hline TE4 & & .860 & & & & \\
\hline TE5 & & .810 & & & & \\
\hline TE3 & & .730 & & & & \\
\hline TE2 & & .650 & & & & \\
\hline TE1 & & .606 & & & & \\
\hline SNS1 & & & .898 & & & \\
\hline SNS2 & & & .887 & & & \\
\hline SNS4 & & & .846 & & & \\
\hline SNS3 & & & .820 & & & \\
\hline ATB2 & & & & .863 & & \\
\hline ATB1 & & & & .792 & & \\
\hline ATB3 & & & & .791 & & \\
\hline ATB4 & & & & .500 & & \\
\hline TK3 & & & & & .866 & \\
\hline TK2 & & & & & .801 & \\
\hline TK1 & & & & & .700 & \\
\hline TK4 & & & & & .690 & \\
\hline MO1 & & & & & & .891 \\
\hline $\mathrm{MO} 3$ & & & & & & .854 \\
\hline $\mathrm{MO} 2$ & & .405 & & & & .508 \\
\hline
\end{tabular}

Rotation method: Promax with Kaiser normalization. Source: own survey (2020)

Rotation converged in 6 iterations

0.05) respectively and statistically significant. It implies that the independent variables have a positive relationship with the dependent variable of the study with a statistically significant level of $p<0.05$ and $n=370$.

\section{Effect analysis of the study variables}

As shown in Table 6, the study independent variables (SNS, ATB, MO, TK, and TF) explained the study dependent variable (TE) by $54.9 \%$. This result indicates that there are other variables that explain the dependent variable by $45.1 \%$ which has not been investigated under this study.

\section{Hypothesis test}

The proposed hypothesis of the study has been tested based on the coefficient of regression and the " $p$ " value of the study variables. The detail result is described as follows: 
Table 5 Correlations of the variables

\begin{tabular}{llllllll}
\hline & Variables & TE & SNS & ATB & MO & TK & TF \\
\hline Pearson correlation & Tax evasion (TE) & 1.000 & & & & & \\
& Subjective norms (SNS) & .240 & 1.000 & & & & \\
& Attitude towards the behavior (ATB) & .318 & .394 & 1.000 & & & \\
& Moral obligation (MO) & .371 & .149 & .376 & 1.000 & & \\
Tax knowledge (TK) & .466 & .096 & .193 & .303 & 1.000 & \\
Tax fairness (TF) & .691 & .236 & .340 & .230 & .398 & 1.000 \\
Sig. (1-tailed) (TE with other variables) & .000 & .000 & .000 & .000 & .000 & .000 \\
\hline
\end{tabular}

Source: own survey (2020)

$H_{1}$. Moral obligation has a negative influence on taxpayers to engage in tax evasion.

As shown in Table 7, moral obligation influences positively the taxpayers to engage in tax evasion activities with a beta value of .177 and $p<.05$. This result entails that the taxpayers are influenced by other stakeholders to engage in tax evasion, and they have low moral value to pay the tax levied by the government. This result is supported by the finding of Alleyne and Harris (2017), Rantelangi and Majid (2018), and Sadjiarto et al. (2020). Thus, the hypothesis related to this variable has been rejected because moral obligation influences positively taxpayers to engage in tax evasion.

\section{$H_{2}$. Tax fairness has a positive influence on taxpayers to engage in tax evasion}

To minimize the participation of taxpayers engaged in tax evasion, tax fairness plays a significant role. The regression result indicates in Table 7 that tax fairness positively influences the taxpayers to engage in tax evasion. This result is similar to the finding of Majid et al., (2017) and contradicts with the finding of Rantelangi and Majid (2018) and Alkhatib et al. (2019). Accordingly, the proposed hypothesis has been accepted because the beta value is .563 and the $p$ value is less than .05 .

\section{$H_{3}$. Tax knowledge has a negative influence on taxpayers to engage in tax evasion}

Table 7 shows that tax knowledge influences the taxpayers positively to engaged in tax evasion. The beta value is .183 and the value is $p=0.00$. It is known that when the taxpayers were not well informed about the importance of tax for the country development and the devastating issues of tax evasion, they will be forced to engage in tax evasion. This finding contradicts the finding of Rantelangi and Majid (2018) and is supported by the finding of AlAdham et al. (2016). To conclude, the proposed

Table 6 Model summary

\begin{tabular}{|c|c|c|c|c|c|c|c|c|c|}
\hline \multirow[t]{2}{*}{ Model } & \multirow[t]{2}{*}{$R$} & \multirow{2}{*}{$\begin{array}{l}R \\
\text { square }\end{array}$} & \multirow{2}{*}{$\begin{array}{l}\text { Adjusted } \\
\text { R square }\end{array}$} & \multirow{2}{*}{$\begin{array}{l}\text { Std. } \\
\text { error of } \\
\text { the } \\
\text { estimate }\end{array}$} & \multicolumn{5}{|l|}{ Change statistics } \\
\hline & & & & & $R$ square change & F change & df1 & df2 & Sig. F change \\
\hline 1 & $.745^{\mathrm{a}}$ & .555 & .549 & .62660 & .587 & 103.408 & 5 & 364 & .000 \\
\hline
\end{tabular}

Source: own survey (2020)

apredictors: (constant), TF, SNS, MO, ATB, TK 
Table 7 Coefficients of variables

\begin{tabular}{|c|c|c|c|c|c|c|}
\hline \multirow{2}{*}{\multicolumn{2}{|c|}{ Model }} & \multicolumn{2}{|c|}{ Unstandardized coefficients } & \multirow{2}{*}{$\begin{array}{l}\text { Standardized coefficients } \\
\text { Beta }\end{array}$} & \multirow[t]{2}{*}{$T$} & \multirow[t]{2}{*}{ Sig. } \\
\hline & & B & Std. error & & & \\
\hline \multirow[t]{6}{*}{1} & (Constant) & .623 & .174 & & 3.589 & .000 \\
\hline & SNS & .050 & .030 & .063 & 1.656 & .099 \\
\hline & ATB & -.001 & .044 & -.001 & -.018 & .985 \\
\hline & $\mathrm{MO}$ & .197 & .043 & .177 & 4.547 & .000 \\
\hline & TK & .174 & .037 & .183 & 4.661 & .000 \\
\hline & TF & .468 & .033 & .563 & 14.021 & .000 \\
\hline
\end{tabular}

Source: own survey (2020)

Dependent variable: TE

hypothesis rejected because tax knowledge positively influenced the taxpayers to engage in tax evasion.

\section{$H_{4}$. Subjective norms have a positive influence on taxpayers engaged in tax evasion}

Table 7 indicates that subjective norms have not been significantly influenced positively by the taxpayers engaged in tax evasion, which means taxpayers were not influenced by others to participate in tax evasion activities. This result is consistent with the finding of Alleyne and Harris (2017). Thus, the proposed hypothesis is rejected because the variable of subjective norms was not statistically significant with a $p$ value of .099 .

$H_{5}$. Tax payers' attitude towards the behavior has a positive influence on taxpayers to engage in tax evasion

As indicated in Table 7, attitudes toward the behavior were not significantly influencing the taxpayers to participate in tax evasion with the $p$ value of .985 . However, according to the study conducted by Alleyne and Harris (2017), attitude toward the behavior significantly predicts the intentions of taxpayers to engage in tax evasion. This finding contradicts with this study result. To conclude, the proposed hypothesis has been rejected because the variable is not statistically significantly influencing the taxpayers to engage in tax evasion activities.

\section{Discussion}

According to Table 7 through the examination of coefficients, moral obligation had a positive effect on tax evasion having a coefficient of .197. This means that a $1 \%$ change in moral obligation keeping the other things remain constant can result to motivate taxpayers to engage in tax evasion by $19.7 \%$ in the same direction. This finding is similar to the result of Alleyne and Harris (2017), Nangih and Dick (2018), Rantelangi and Majid (2018), and Sadjiarto et al. (2020). Tax knowledge had a positive effect on tax evasion having a coefficient of .174. This indicates that a $1 \%$ change in tax knowledge keeping the other things constant can result in a change in taxpayers to engage in tax evasion by $17.4 \%$ in the same direction. This finding contradicts the finding of Rantelangi and Majid (2018) and is similar to the finding of AlAdham et al. (2016) and Thu (2017). Tax fairness also had a positive effect on tax evasion having a coefficient of .468. This implies that a $1 \%$ change in tax fairness keeping the other things remain constant can result in a change in 
taxpayers engage in tax evasion by $.468 \%$ in the same direction. This result is similar to the finding of Majid et al. (2017) and contradicts the finding of Alkhatib et al. (2019) and Rantelangi and Majid (2018). Thus, the final model of the study would be:

Tax evasion $=.623+.197 \mathrm{MO}+.174 \mathrm{TK}+.468 \mathrm{TF}$

To generalize, the standardized beta coefficient indicates that tax fairness highly affects taxpayers to engage in tax evasion by $56.3 \%$, tax knowledge affects secondly taxpayers to engage in tax evasion by $18.3 \%$, and moral obligation affects taxpayers to engage in tax evasion by $17.7 \%$. The remaining variables subjective norms and attitude towards the behavior were not statistically significant.

\section{Conclusion and recommendations}

Every citizen of the country was subjected to pay the tax of the country levied by the authority that administered the revenue. However, the taxpayer may be reluctant to pay a tax based on their revenue. There are push factors that instigate payers to engage in tax evasion. Sometimes the payers may be convinced themselves that being engaged in tax evasion is ethical, others may consider it unethical. They may argue "I Do Not Receive Benefits, Therefore I Do Not Have to Pay" (Robert, 2012). This study tried to examine the factors that influence taxpayers to engage in tax evasion by identifying five factors namely moral obligation, tax fairness, tax knowledge, subjective norms, and taxpayers' attitude towards the behavior. The study findings based on the result analysis described as follows.

The correlation analysis of the study shows that there was a positive and statistically significant relationship between independent variables with the dependent variable (tax evasion). The regression result, on the other hand, revealed that tax knowledge affects taxpayers to participate in tax evasion activities with a statistically significant level. This finding can be evidence that the knowledge of the taxpayers regarding the importance of tax is limited. Because according to the regression result, they engaged in the tax evasion activities in the study area. The other factor that affects taxpayers to engage in tax evasion is tax fairness. The regression result of tax fairness supported that taxpayers have been affected by the fairness of the tax system in the study area to participate in tax evasion. The finding confirms that the tax charged by the government is not fair for payers. Thus, we can conclude that due to the absence of tax fairness taxpayers are engaged in tax evasion in the city administration. The other variable moral obligation regression result confirms that moral obligation affects positively taxpayers to engage in tax evasion. This is signal that taxpayers did not know the moral value of retaining from tax evasion that is why the moral obligation results in positive and statistical significance. Generally, tax fairness highly affects taxpayers to evade taxes, tax knowledge affects secondly, and moral obligation affected tax payers thirdly to evade tax in the city administration.

Based on the findings, the following recommendations have been forwarded by the researcher. The first one is creating a fair tax payment system, or charging fair tax for the payers helps to reduce the participation of payers in tax evasion. The second recommendation is cascading different training related to tax will help taxpayers to pay a tax based on their annual income. The last recommendation is related to tax moral or moral obligation. The moral is an abounding rule for human beings to know the right and wrong activities. The authority is better to strive to recognize the payers about the moral obligations of the payers and better to inform to the payers to think about the shattering effect of tax evasion for the country development and city as well. 


\section{Further future lines of research will attempt to:}

- Investigate the employees' side of tax authority and the perception of the community towards tax evasion.

- Explore other influencing factors that affect tax payers to engage in tax evasion which are not incorporated under this study.

- Conducting a comparative study on one city, region, and country with others.

\section{Suggestion for future study}

This study addresses only one city administration in Amhara region; other researchers are better to undertake the study on one more cities.

\section{Abbreviations}

ATB: Attitude towards the behavior; MO: Moral obligation; MSEs: Micro and small enterprises; SNS: Subjective norms; TE: Tax evasion; TF: Tax fairness; TK: Tax knowledge

\section{Acknowledgements}

I am grateful to all anonymous reviewers, my respondents, and Woldia City administration revenue office experts sharing the required information.

\section{Author's contributions}

The research was done independently. I have carried out the whole work of the study. The author read and approved the final manuscript.

\section{Funding}

The author has not received a fund from any organization.

Availability of data and materials

All data are included in the manuscript and available on hand too.

\section{Competing interests}

The author declares that there are no competing interest.

Received: 1 October 2020 Accepted: 9 December 2020

Published online: 16 February 2021

\section{References}

Abera, A. A. (2019). Factors affecting presumptive tax collection in Ethiopia: Evidence from category " $\mathrm{C}^{\text {" }}$ taxpayers in Bahir Dar City. Journal of Tax Administration, 5(2), 74-96.

Al Baaj, Q. M. A., Al Marshedi, A. A. S., \& Al-Laban, D. A. A. (2018). The impact of electronic taxation on reducing tax evasion methods of Iraqi companies listed in the Iraqi stock exchange. Academy of Accounting and Financial Studies Journal, 22(4) Retrieved from: www.abacademies.org/articles/.

AlAdham, M. A. A., Abukhadijeh, M. A., \& Qasem, M. F. (2016). Tax evasion and tax awareness evidence from Jordan. International Business Research, 9(12) https://doi.org/10.5539/ibr.v9n12p65.

Alkhatib, A. A., Abdul-Jabbar, H., Abuamria, F., \& Rahhal, A. (2019). The effects of social influence factors on income tax evasion among the Palestinian SMEs. International Journal of Advanced Science and Technology, 28(17), 690-700.

Alleyne, P., \& Harris, T. (2017). Antecedents of taxpayers' intentions to engage in tax evasion: Evidence from Barbados. Journal of Financial Reporting and Accounting (Emerald Publishing Limited), 15(1), 2-21 https://doi.org/10.1108/JFRA-12-2015-0107.

Allingham, M. G., \& Sandmo, A. (1972). Income tax evasion: a theoretical analysis. Journal of Public Economics, 1(3-4), $323-338$.

Alm, J., \& Torgler, B. (2006). Culture differences and tax morale in the United States and in Europe. Journal of Economic Psychology, 27(2), 224-246.

Ameyaw, B., Addai, B., Ashalley, E., \& Quaye, I. (2015). The effects of personal income tax evasion on socio-economic development in Ghana: A case study of the informal sector. British Journal of Economics, Management \& Trade (Sciencedomain international), 10(4), 1-14 https://doi.org/10.9734/BJEMT/2015/19267.

Annan, B., Bekoe, W., \& Nketiah-Amponsah, E. (2014). Determinants of Tax Evasion in Ghana: 1970-2010. International Journal of Economic Sciences and Applied Research, 6(3), 97-121.

Aumeerun, B., Jugurnath, \& Soondrum, H. (2016). Tax evasion: Empirical evidence from sub-Saharan Africa. Journal of Accounting and Taxation (Academic Journals), 8(7), 70-80 https://doi.org/10.5897/JAT2016.022.

Benk, S., Budak, T., \& Cakmak, A. F. (2012). Tax professionals' perceptions of tax fairness: Survey evidence in Turkey. International Journal of Business and Social Science, 3(2) Centre for Promoting Ideas, USA.

Dalu, T., Maposa, V. G., Pabwaungana, S., \& Dalu, T. (2012). The impact of tax evasion and avoidance on the economy: a case of Harare, Zimbabwe. African Journal Economic and Sustainable Development, 1(3), 284-296.

degl'Innocenti, D. G., \& Rablen, M. D. (2019). Tax evasion on a social network. Journal of Economic Behavior and Organization (Elsevier B.V), 79-91 https://doi.org/10.1016/j.jebo.2019.11.001.

Fagbemi, T. O., Uadiale, O. M., \& Noah, A. O. (2010). The ethics of tax evasion: Perceptual evidence from Nigeria. European Journal of Social Sciences, 17(3) 
Feld, L. P., \& Frey, B. S. (2007). Tax Compliance as the Result of a Psychological Tax Contract: The Role of Incentives and Responsive Regulation. Law \& Policy, 29(1), 102-120.

Frey, B. S., \& Oberholzer-Gee, F. (1997). The Cost of Price Incentives: An Empirical Analysis of Motivation Crowding- Out. The American Economic Review, 87(4), 746-755.

Gallemore, J., \& Labro, E. (2015). The importance of the internal information environment for tax avoidance. Journal of Accounting and Economics, 60(1), 149-167.

Gandhi, V. P., Edrill, L. P., Mackenzie, G. A., Manas-Anton, L. A., Modi, J. R., Richupan, S., .. Shome, P. (1995). Supply-side tax policy: Its relevance to developing countries. International Monteray Fund.

James, S. R., \& Nobes, C. (1999). The Economics of Taxation: Principles, Policy, and Practice, (vol. 7). Financal Times Management

Kim, S. (2008). Does political intention affect tax evasion? Journal of Policy Modeling, 30(3), 401-415.

Majid, N., Rantelangi, C., \& Iskandar (2017). Tax evasion: Is it ethical or unethical? (based on Samarinda taxpayers' perception). In Mulawarman international conference on economics and business (MICEB 2017), (pp. 13-18). Atlantis Press http:// creativecommons.org/licenses/by-nc/4.0/.

McGee, R. W. (2006). Three views on the ethics of tax evasion. Journal of Business Ethics, 67(1), 15-35.

Mughal, M. M. (2012). Reasons of Tax Avoidance and Tax Evasion: Reflections from Pakistan. Journal of Economics and Behavioral Studies, 4(4), 217-222.

Nabaweesi, J. (2009). Social norms and tax compliance among small business enterprises in Uganda (Master's thesis). Retrieved from http://makir.mak.ac.ug/handle/10570/2525

Nangih, E., \& Dick, N. (2018). An empirical review of the determinants of tax evasion in Nigeria: Emphasis on the informal sector operators in Port Harcourt Metropolis. Journal of Accounting and Financial Management, 4(3) http://www.iiardpub. org/.

Ozili, P. K. (2020). Tax evasion and financial instability. Journal of Financial Crime. Emerald Publishing Limited, 27(2), 531-539 https://doi.org/10.1108/JFC-04-2019-0051.

Palil, M. R., Malek, M. M., \& Jaguli, A. R. (2016). Issues, challenges and problems with tax evasion: The institutional factors approach. Gadjah Mada International Journal of Busines, 18(2), 187-206.

Poudel, R. L. (2017). Tax knowledge among university teachers in Pokhara. The Journal of Nepalese Bussiness Studies, 10(1).

Puspitasari, E., \& Meiranto, W. (2014). Motivational postures in tax compliance decisions: An experimental studies. International Journal of Business, Economics and Law, 5(1), 100-110.

Putra, P. D., Syah, D. H., \& Sriwedari, T. (2018). Tax avoidance: Evidence of as a proof of agency theory and tax planning. International Journal of Research and Review, 5(9), 2454-2223.

Rantelangi, C., \& Majid, N. (2018). Factors that influence the taxpayers' perception on the tax evasion. In Advances in economics, business and management research (AEBMR), (p. 35). Atlantis Press.

Robert, W. M. G. (2012). The ethics of tax evasion; perspectives in theory and practice. North Miami: Springer Science+Business Media https://doi.org/10.1007/978-1-4614-1287-8.

Sadjiarto, A., Susanto, A. N., Yuniar, E., \& Hartanto, M. G. (2020). Factors affecting perception of tax evasion among Chindos. In Advances in economics, business and management research:23rd Asian Forum of Business Education(AFBE 2019), 144, (pp. 487-493). Atlantis Press SARL.

Saxunova, D., \& Szarkova, R. (2018). Global Efforts of Tax Authorities and Tax Evasion Challenge. Journal of Eastern Europe Research in Business and Economics, 2018, 1-14.

Storm, A. (2013). Establishing The Link Between Money Laundering And Tax Evasion. International Business \& Economics Research Journal (IBER), 12(11), 1437

Terzić, S. (2017). Model for determining subjective and objective factors of tax evasion. Notitia - Journal for Economic, Business and Social Issues, Notitia Ltd., 1(3), 49-62.

Thu, H. N. (2017). Determinants to tax evasion behavior in Vietnam. Journal of Management and Sustainability Canadian Center of Science and Education. https://doi.org/10.5539/jms.v7n4p123.

Torgler, B., Demir, I. C., Macintyre, A., \& Schaffner, M. (2008). Causes and Consequences of Tax Morale: An Empirical Investigation. Economic Analysis and Policy, 38(2), 313-339.

Turner, Sean C. (2010). Essays on Crime and Tax Evasion. Dissertation, Georgia State University, 2010. https://scholarworks.gsu. edu/econ_diss/64

Woldia City Administration Revenue Office (2019/2020). 2012E.C annual report. Woldia.

Yamane, T. (1967). Statistics: An Introductory Analysis, (2nd ed., ). New York: Harper and Row.

Zucman, G. (2014). Taxing accross borders: Tracking personal wealth and corporate profits. The Journal of Economic Perspectives, 28(4), 121-148.

\section{Publisher's Note}

Springer Nature remains neutral with regard to jurisdictional claims in published maps and institutional affiliations. 